\title{
What are multiple primary malignancies?
}

\author{
ANNA MARIA ROMASZKOD-F, ANNA DOBOSZYŃSKA ${ }^{\mathrm{D}-\mathrm{F}}$
}

Department of Pulmonology and Infectiology, University of Warmia and Mazury in Olsztyn

A - Study Design, B - Data Collection, C - Statistical Analysis, D - Data Interpretation, E - Manuscript Preparation, F- Literature Search, G - Funds Collection

Summary Over the past 30 years, the incidence of cancer in Poland has more than doubled. Advances in technology, early diagnosis and improved treatment make more and more malignancies curable. An increase in the survival of cancer patients has also been observed. An increased rate of survival leads to the development of subsequent malignancies. Their cause is yet unclear however, chemotherapy as well as genetic and environmental factors may be involved in the process. The key prognostic factors for patients who were once diagnosed with cancer are: type of cancer, its stage and available treatment options. The aim of this work is to introduce the issue of multiple primary malignancies, with particular emphasis on their epidemiology. From the perspective of the whole population, the occurrence of multiple malignancies is quite rare. Triple or quadruple malignancies are even less common. Multiple malignancies may develop at any age, although, as it is shown in this paper, the type of cancer, its stage and location vary depending on the age at which the first and later subsequent cancers have presented. The most frequently found subsequent cancers are: colon cancer, lung cancer, cancers of the genital system and breast cancer. Based on statistical analysis and current literature, we discuss the risk of developing a second malignancy depending on the type of cancer that was diagnosed first.

Key words: early diagnosis, multiple primary malignancies, primary health care.

Romaszko A.M, Doboszyńska A. What are multiple primary malignancies? Fam Med Prim Care Rev 2017; 19(1): 75-79, doi: 10.5114/ fmpcr.2017.65096.

\section{Incidence}

Data shows that 140,500 people in Poland, including approximately 70 thousand men and 70.5 thousand women are diagnosed with cancer each year. In 2014, the Government Population Council published a bulletin regarding cancer incidence and mortality in Poland. The most common locations of cancer in both men and women, according to the National Cancer Registry in 2014, are presented in Table 1.

\begin{tabular}{|l|l|l|l|}
\hline \multicolumn{4}{|l|}{ Table 1. Most common locations of cancer } \\
\hline Location & $\begin{array}{l}\text { Percentage } \\
(\%)\end{array}$ & Location & $\begin{array}{l}\text { Percentage } \\
(\%)\end{array}$ \\
\hline Men & 21 & Women \\
\hline Lungs & \multicolumn{1}{|l|}{} \\
\hline Prostate & 13 & Breast & 22 \\
\hline Colon & 12 & Lolon & 10 \\
\hline Urinary bladder & 7 & Corpus uteri & 7 \\
\hline Stomach & 5 & Ovary & 5 \\
\hline Kidney & 4 & Cervix uteri & 4 \\
\hline Larynx & 3 & Kidney & 3 \\
\hline $\begin{array}{l}\text { Hematopoietic } \\
\text { system }\end{array}$ & 2 & Stomach & 3 \\
\hline Lymphatic system & 2 & Thyroid & 3 \\
\hline Others & 30 & Others & 34 \\
\hline
\end{tabular}

Compared to other countries of the European Union, the incidence of malignant cancer is lower in Poland: approximately $20 \%$ in men, and approximately $10 \%$ in women [1-3].

\section{Mortality}

Cancer is the second most common cause of death in Poland. Ninety-six thousand individuals die annually from cancer, which constitutes $25 \%$ of all cases of death. The mortality associated with malignant cancers has increased by approximately 2.4 times in the last 50 years. Lung cancer is the most common cause of death in men (1/3) and women (1/6). For males, that is followed by colorectal cancers $(12 \%)$, prostatic cancer $(8 \%)$, gastric cancer, bladder cancer, renal cancer, leukemia and brain cancer. In the case of females, these are: breast cancer (13\%), colorectal cancer (12\%), ovarian cancer, pancreatic cancer, gastric cancer, cervical cancer, brain tumors and leukemia. It is believed that, considering various factors which include prolonged life expectancy and exposure to harmful agents (e.g. tobacco smoke), cancer morbidity and mortality will systematically rise until it becomes the principal cause of death before the age of $65[4,5]$. The epidemiological situation is to some extent similar to that observed at the beginning of the $19^{\text {th }}$ century, when the increasing availability of antibiotics led to a shift where cardiovascular diseases became the primary cause of death instead of infectious diseases [6]. Progress, both in primary prevention and treatment of cardiovascular diseases in developed countries, is one of the causes of the observed situation. Average life expectancy has increased by approximately 6.2 years since 1990 (from 65.3 years in 1990 to 71.5 years in 2013) and with it the leading cause of death has also changed [7].

Demographic prognoses developed by the Government Population Council in Poland suggest that by 2025 , the morbidity of malignant cancers of the colon, breast and prostate will increase and the mortality associated with cervical cancer will fall. The increasing morbidity of cancer, along with progress in the diagnostics and therapy of oncological diseases, will also contribute to an increased morbidity due to MPMNs (Multiple Primary Malignant Neoplasms) [8]. 


\section{Objectives}

The aim of this work is to introduce the issue of multiple primary malignancies, with particular emphasis on their epidemiology.

\section{The definition of MPMNs}

The term MPMNs (Multiple Primary Malignant Neoplasm) was first used by T. Billroth [9] in 1889 and was first reported by S. Warren and O. Gates in 1932 [10]. An official WHO definition was published in 1995. Cancer is defined as primary if it develops in situ, is not a part of an existing neoplastic process and there are no signs of its dissemination, metastasis or recurrence. A proliferative process which is diagnosed in one organ or in double organs, may be considered a single neoplasm if it possesses the same histological structure in all locations. Sometimes more precise tests, e.g. genetic analyses, allow to determine the differences between foci, thus allowing us to distinguish them. Systemic or multifocal cancers, such as lymphomas, leukemia, Kaposi sarcoma and mesothelioma, involving multiple organs, are diagnosed as a single neoplasm. Skin cancers pose a problem, but according to WHO guidelines, only the first tumor of a given histology type, located anywhere on the skin, is defined as an occurrence of a single neoplastic disease.

Multiple neoplasms are defined as histopathologically confirmed two or more different tumors that developed in distinct locations or within the same organ, as well as single neoplasms having numerous foci, but the precise origin of which could not be determined $[3,11,12]$. In the group of patients initially diagnosed with multiple neoplasms, the possibility that some of the tumors are metastatic needs to be excluded. Such patients, with metastatic lesions should not be classified as patients with multiple neoplasms. This may be particularly difficult when the result of the histopathological examination is inconclusive, a situation common when diagnosing head and neck cancers.

The diagnosis of multiple primary neoplasms does not depend on the time of their development. However, in respect to time, cancers may be classified as synchronous and metachronous $[13,14]$. A synchronous cancer is defined as an independent tumor that follows the first one in sequence by 6 months. Metachronous cancers are defined as those that develop later than 6 months after the first neoplasm.

The issue of MPMNs has become more common in recent years. Both the rise of cancer incidence and a more favorable prognosis associated with oncological treatment contribute to its occurrence. It should be noted that treatment administered to oncological patients, such as chemotherapy or radiotherapy also has a prooncogenic effect $[15,16]$. The presence of these factors increases the incidence of subsequent cancers which is significantly higher compared to the incidence of cancer in the general population $[17,18]$. Curtis et al. demonstrated an 11.9-fold increased of risk of leukemia after breast cancer chemotherapy treatment with alkylating agents $[19,20]$. Murakami et al. demonstrated an increased risk of subsequent breast cancer post-radiotherapy of the first tumor [21]. It has also been proven that after radiotherapy of breast cancer, there is an increased incidence of lung cancer [22].

In multiple metachronous cancer, patients achieving complete remission after chemotherapy frequently die from other aggressive supportive therapy. This is why it is particularly important to determine the least harmful treatment, so as to minimize the risk of developing a subsequent cancer and to manage optimal diagnostic assessment after oncological treatment, including early diagnosis and determining the nature of changes occurring during the observation period. Some of these changes may not be a manifestation of cancer recurrence, but could be a different, independent cancer [23]. In addition, the prognosis in patients with metachronous cancers is worse than in patients with synchronous cancers [24].
Both genetic factors and oncogenic viruses may lead to the development of new tumors.

Schildgen et al. [25] have detected the presence of Human Bocavirus genetic material in 11/60 (18.3\%) archived samples of lung cancer and 9/44 (20.5\%) samples of colorectal cancer.

Wang et al. [26] examined the genetic material of 70 lung tumors from 30 patients. In all 30 cases, loss of heterozygosity (LOH), in at least one in four of the six polymorphic microsatellite markers was shown. Identical genetic changes were found in $23 / 30$ cases $(77 \%)$ which confirms the monoclonal origin of these changes.

From this perspective, a past neoplastic disease may and should be treated as a risk factor for other types of cancer.

\section{Multiple neoplasms: prevalence and occurrence}

The prevalence of MMPNs ranges between 0.73 and $11.7 \%$ [27]. Cases of double neoplasms are most common: $3-5 \%$; followed by triple neoplasms: $0.5 \%$; and quadruple neoplasms: $0.3 \%$ [28]. Interestingly, in contrast to the previously mentioned general incidences, multiple neoplasms occur more often in males. The incidence of male to female ratio is approximately 2.5:1 [29]. The most common locations of primary multiple neoplasms are in the nasopharynx, lungs, colon and breast [30, 31]. Bittorf et al. [32] demonstrated that the mean time difference between the development of the first and the second cancer is 4 years. Feyerabend et al. [33] reported a time of 5.7 years. Considering the time interval, extentson of diagnostic and control procedures over this period of time after treating the first tumor might be considered.

The risk of developing a subsequent neoplasm remains increased for as long as 20 years after the first diagnosis. An increased risk of development of another cancer after the first neoplasm of the respiratory system by as much as $49 \%$ was demonstrated in patients who survived 10 or more years [34].

The knowledge of incidence rates of subsequent neoplasms is important when considering secondary prophylaxis. This helps to direct diagnostic procedures towards the most probable secondary cancer.

Both the risk of developing a subsequent neoplasm and its probable location changes in time since the first cancer is treated. The most common cancers in both men and women are lung and colorectal neoplasms. Additionally, in women, breast cancer is also among the first three as is prostate cancer in men. Patients treated for lung or bronchial cancer are at a greater risk of developing lung cancer or a colorectal carcinoma once again during the first year after treatment. Occurrence of neoplasms of the head and neck are often common during the period of 1 to 4 years following the principal diagnosis. Radiotherapy for non-small cell lung carcinoma is associated with a six-fold increase of the risk of esophageal cancer during the 5-9 year follow-up period, and with as high as an 11-fold increase after 10 years of follow-up [34]. It was also demonstrated that both non-small cell and small cell lung cancer is associated with an increased risk of developing thyroid cancer during the first year after diagnosis [34]. The risk of developing other neoplasms after the treatment of colorectal cancer is $7 \%$, with a higher index of development associated with subsequent colorectal cancer and prostate cancer. Treatment for breast cancer is usually associated with the development of digestive system neoplasms, among which colorectal carcinoma is most probable. The diagnosis and treatment of prostatic cancer is most often associated with the development of digestive cancer - most probably in the colon; and of respiratory cancer - in the lungs.

The highest probabilities of subsequent cancers in women and men are presented in Figures 1 and 2 . The Figures should be read in the following manner - among women who have a subsequent malignant cancer after the treatment of breast cancer, as much as $41.45 \%$ will have subsequent breast cancer, $9.3 \%$ will have colorectal carcinoma, and so on. 


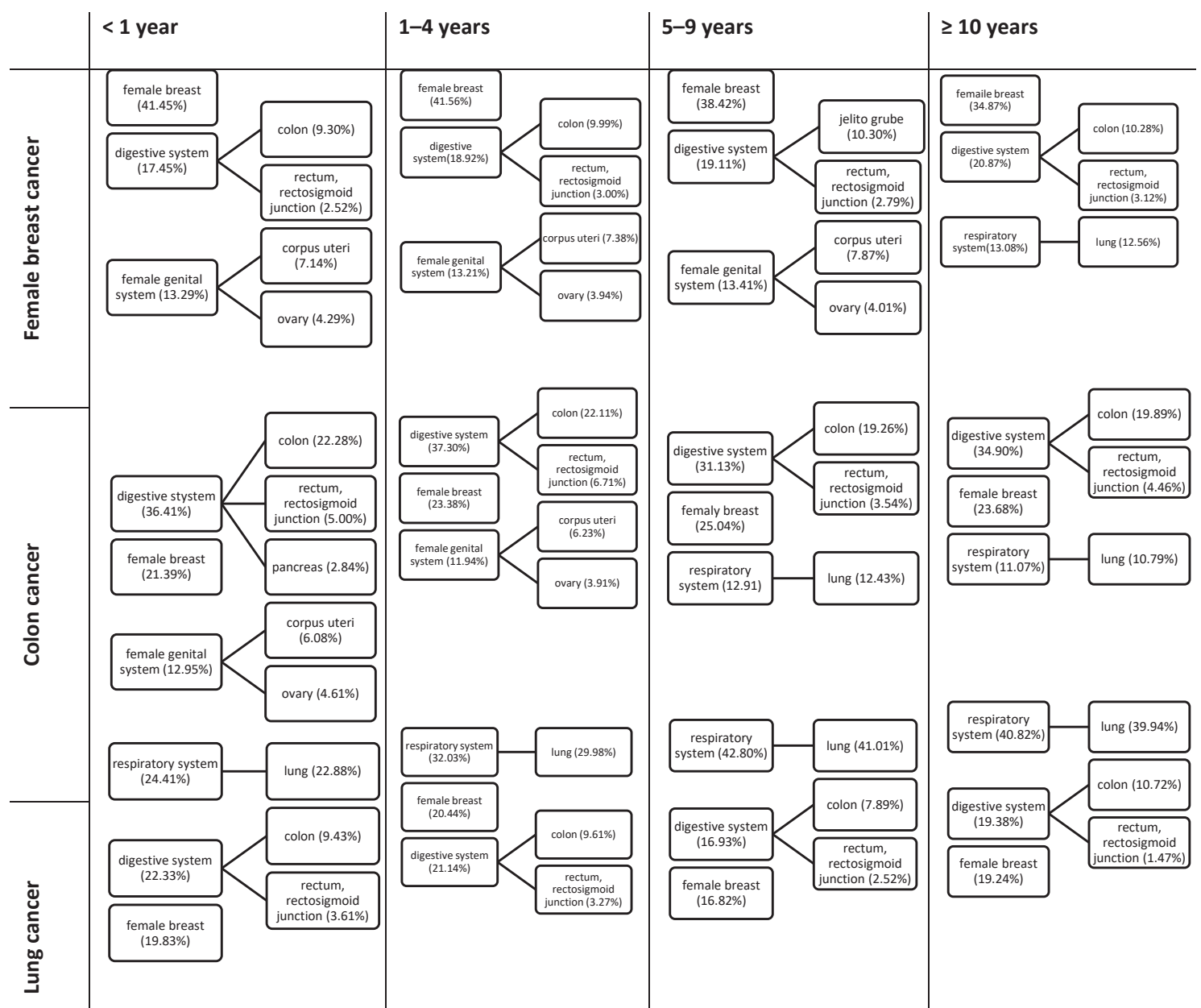

Figure 1. The probability of developing a specific subsequent malignancy among women who had been previously treated for cancer Graphic design based on SEER Cancer Registries

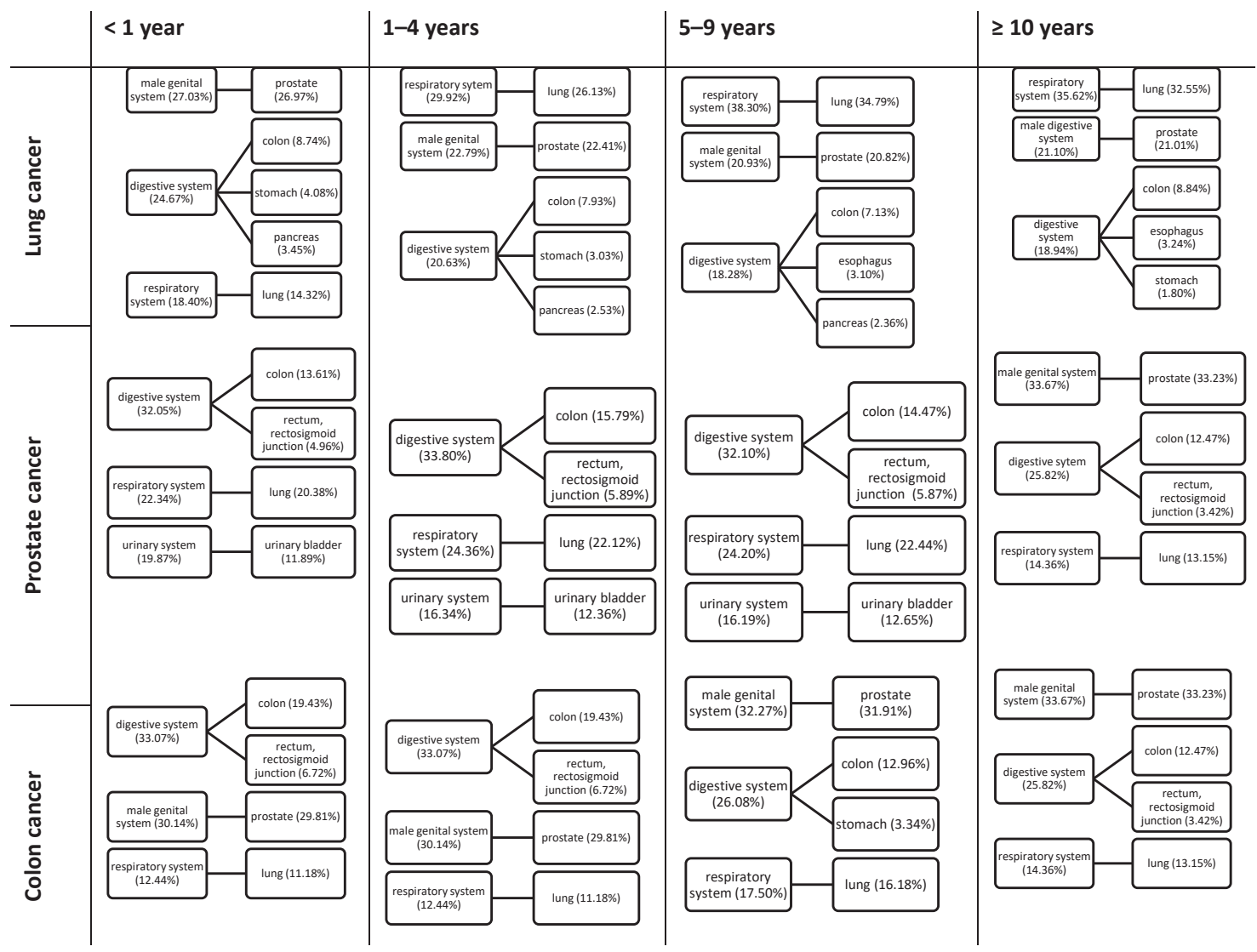

Figure 2. The probability of developing a specific subsequent malignancy among men who had been previously treated for cancer Graphic design based on SEER Cancer Registries 


\section{Conclusions}

A history of neoplastic disease should be treated as a risk factor for cancer. Knowledge of the most common secondary

neoplasms may facilitate early diagnostics and therefore lead to more efficient treatment.

Source of funding: This work was funded by the authors' resources. Conflict of interest: The authors declare no conflict of interests. Language verification: e-transmed.pl.

\section{References}

1. Access to innovative cancer drugs in Poland in comparison with selected European Union countries and Switzerland. EY Poland; 2015. Available from URL: https://www.alivia.org.pl/raport2015/05_05_2015_Raport_wersja_EN.pdf.

2. Potrykowska A, Strzelecki Z, Szymborki J, et al. Zachorowalność i umieralność na nowotwory a sytuacja demograficzna Polski. Warszawa: Rządowa Rada Ludnościowa; 2014.

3. Didkowska J, Wojciechowska U. Zachorowania i zgony na nowotwory złośliwe w Polsce [cited 01.12.2015]. Available from URL: http:// onkologia.org.pl/k/epidemiologia/.

4. Roszkowski K. Rak płuca w praktyce lekarza rodzinnego. Fam Med Prim Care Rev 2011; 13(2): 343-346.

5. Porth C. Essentials of pathophysiology: concepts of altered health states: Lippincott Williams \& Wilkins; 2011; 131-159.

6. Mathers CD, Lopez AD, Murray CJL. The burden of disease and mortality by condition: data, methods, and results for 2001. In: Lopez AD, Mathers CD, Ezzati M, et al., eds. Global burden of disease and risk factors. Washington (DC): The International Bank for Reconstruction and Development/The World Bank; 2006.

7. GBD 2013 Mortality and Causes of Death Collaborators. Global, regional, and national age-sex specific all-cause and cause-specific mortality for 240 causes of death, 1990-2013: a systematic analysis for the Global Burden of Disease Study 2013. Lancet 2015; 385(9963): 117-171.

8. Bażydło M, Karakiewicz B, Kotwas A, et al. Ageing society - a review of strategies for action. Prog Health Sci 2014; 4(1): $220-228$.

9. Billroth T. General surgical pathology and therapy. Guidance for students and physicians. Lecture. Khirurgiia 1991; 10(10): 136-143 [in Russian].

10. Warren S, Gates O. Multiple primary malignant tumors. A survey of the literature and a statistical study. Am J Cancer 1932; 16 : 1358.

11. Sosnowski R, Ligaj M, Demkow T, et al. Jednoczasowe współistnienie raka nerkowokomórkowego i raka urotelialnego miedniczki w jednej nerce. Urol Pol 2006; 59(2).

12. SEER Training Modules, Multiple Primary Neoplasms. U. S. National Institutes of Health, National Cancer Institute [serial online] 2015 [cited 01.12.2015]. Available from URL: http://training.seer.cancer.gov/.

13. Vaamonde $\mathrm{P}$, Martin C, del Rio M, et al. Second primary malignancies in patients with cancer of the head and neck. Otolaryngol Head Neck Surg 2003; 129(1): 65-70.

14. Suzuki T, Takahashi $\mathrm{H}$, Yao K, et al. Multiple primary malignancies in the head and neck: a clinical review of 121 patients. Acta Otolaryngol Suppl 2002; 547: 88-92.

15. Wolff AC, Blackford AL, Visvanathan K, et al. Risk of marrow neoplasms after adjuvant breast cancer therapy: the national comprehensive cancer network experience. J Clin Oncol 2015; 33(4): 340-348.

16. MacKinnon A, Hyett A, Gui GPH. A woman with multiple primary malignancies - the Li-Fraumeni like syndrome. CME BREAST 2011; $1(1): 26-27$.

17. Crocetti E, Buiatti E, Falini P, et al. Multiple primary cancer incidence in Italy. Eur J Cancer 2001; 37(18): 2449-2456.

18. Youlden DR, Baade PD. The relative risk of second primary cancers in Queensland, Australia: a retrospective cohort study. BMC Cancer 2011; 11: 83

19. Curtis RE, Boice JD, Jr., Moloney WC, et al. Leukemia following chemotherapy for breast cancer. Cancer Res 1990; 50(9): 2741-2746.

20. Morton LM, Dores GM, Tucker MA, et al. Evolving risk of therapy-related acute myeloid leukemia following cancer chemotherapy among adults in the United States, 1975-2008. Blood 2013; 121(15): 2996-3004.

21. Murakami R, Hiyama T, Hanai A, et al. Second primary cancers following female breast cancer in Osaka, Japan - a population-based cohort study. Jpn J Clin Oncol 1987; 17(4): 293-302.

22. Darby SC, McGale P, Taylor CW, et al. Long-term mortality from heart disease and lung cancer after radiotherapy for early breast cancer: prospective cohort study of about 300,000 women in US SEER cancer registries. Lancet Oncol 2005; 6(8): 557-565.

23. Bottoni U, Clerico R, Paolino G, et al. Appearance of malignant melanoma after a non-cutaneous cancer diagnosis. Ecancermedicalscience 2013; 7: 315.

24. Ibrahim NY, Sroor MY, Darwish DO. Impact of bilateral breast cancer on prognosis: synchronous versus metachronous tumors. Asian Pac J Cancer Prev 2015; 16(3): 1007-1010.

25. Schildgen V, Malecki M, Tillmann R-L, et al. The human bocavirus is associated with some lung and colorectal cancers and persists in solid tumors. PLoS ONE 2013; 8(6): e68020.

26. Wang X, Wang M, MacLennan GT, et al. Evidence for common clonal origin of multifocal lung cancers. J Nat/ Cancer Inst 2009; 101(8): 560-570.

27. Demandante CG, Troyer DA, Miles TP. Multiple primary malignant neoplasms: case report and a comprehensive review of the literature. Am J Clin Oncol 2003; 26(1): 79-83.

28. Sakashita $\mathrm{H}$, Miyata $\mathrm{M}$, Miyamoto $\mathrm{H}$, et al. A case of quadruple cancer, including triple cancers in the head and neck region. $J$ Oral Maxillofac Surg 1996; 54(4): 501-505.

29. Cahan WG. Multiple primary cancers of the lung, esophagus, and other sites. Cancer 1977; 40(4 Suppl.): 1954-1960.

30. Li W, Zhan Y, Li G. Double cancers: a clinical analysis of 156 cases. Zhonghua Zhong Liu Za Zhi 1996; 18(4): $296-298$ [in Chinese].

31. Levi F, Randimbison L, Maspoli-Conconi M, et al. Incidence of second sarcomas: a cancer registry-based study. Cancer Causes Control 2014; 25(4): 473-477.

32. Bittorf B, Kessler H, Merkel S, et al. Multiple primary malignancies: an epidemiological and pedigree analysis of 57 patients with at least three tumours. Eur J Surg Oncol 2001; 27(3): 302-313.

33. Feyerabend T, Richter E, Brandt A. Multiple malignomas an analysis of 357 patients. Strahlanter Onkol 1991; 167(4): 214-219.

34. Curtis RE, Freedman DM, Ron E, et al. New malignancies among cancer survivors. SEER cancer registries 1973-2000. National Cancer Institute, NIH Publ. No. 05-5302. Bethesda, MD, 2006. Avaliable from URL: https://seer.cancer.gov/archive/publications/mpmono/ MPMonograph_complete.pdf. 
Tables: 2

Figures: 0

References: 34

Received: 15.01.2016

Revised: 6.02.2016

Accepted: 6.02.2016

Address for correspondence:

Anna Romaszko, MD

Katedra Pulmonologii i Infekcjologii UWM

ul. Jagiellońska 78

10-357 Olsztyn

Polska

Tel.: +48 89 532-29-59

E-mail: annama90@wp.pl 